Article

\title{
Comparative Analysis of the Complete Mitochondrial Genomes of Five Species of Ricaniidae (Hemiptera: Fulgoromorpha) and Phylogenetic Implications
}

\author{
Huan Zhang ${ }^{1} \mathbb{D}$, Wei Fang ${ }^{1}$, Xiaoyun Zhao ${ }^{1}$, Xin Jiang ${ }^{1}$, Adam Stroiński ${ }^{2}$ and Daozheng Qin ${ }^{1, * \mathbb{D}}$ \\ 1 Key Laboratory of Plant Protection Resources and Pest Management of the Ministry of Education, \\ Entomological Museum, Northwest A\&F University, Yangling, Xianyang 712100, \\ China;2020060097@nwafu.edu.cn (H.Z.); F15729513368@163.com (W.F.); zhaoxiaoyun228016@163.com (X.Z.); \\ Oasis221906@163.com (X.J.) \\ 2 Museum and Institute of Zoology, Polish Academy of Sciences, Wilcza 64, 00-679 Warszawa, Poland; \\ adam@miiz.waw.pl \\ * Correspondence: qindaozh@nwsuaf.edu.cn
}

check for updates

Citation: Zhang, H.; Fang, W.; Zhao, X.; Jiang, X.; Stroiński, A.; Qin, D.

Comparative Analysis of the

Complete Mitochondrial Genomes of Five Species of Ricaniidae (Hemiptera: Fulgoromorpha) and Phylogenetic Implications. Biology 2022, 11, 92. https://doi.org/ 10.3390/biology11010092

Academic Editor: Klaus H. Hoffmann

Received: 23 November 2021

Accepted: 3 January 2022

Published: 7 January 2022

Publisher's Note: MDPI stays neutral with regard to jurisdictional claims in published maps and institutional affiliations.

Copyright: (C) 2022 by the authors. Licensee MDPI, Basel, Switzerland. This article is an open access article distributed under the terms and conditions of the Creative Commons Attribution (CC BY) license (https:// creativecommons.org/licenses/by/ $4.0 /)$.
Simple Summary: Although previous studies have recently explored the phylogenetic relationships among the planthopper families, the taxonomic relationships between Ricaniidae and other families of Fulgoroidea need to be further explored. Meanwhile, the morphological definitions of the two largest genera, Pochazia Amyot \& Serville, 1843 and Ricania Germar, 1818 (the type genus of Ricaniidae) remain controversial, and their monophyly status has never been established. This study aims to clarify the relationship of Ricaniidae with other families of Fulgoroidea and to provide evidence to clarify the differences between these two related genera for species attribution. Our results support the monophyly of Ricaniidae and the sister group status of the two families Flatidae and Ricaniidae but fail to support the monophyly of Pochazia and Ricania. Diagnoses between these two genera cannot be resolved until more evidence is acquired. This study provides new evidence toward the phylogenetic analysis and revision of the distinguishing characteristics of related genera in this family.

\begin{abstract}
Ricaniidae is a relatively small planthopper family with about 69 genera and 442 species worldwide. Members of this family occur throughout the warm temperate and tropical regions. Some species cause devastating damage to major agricultural and economic plants. However, the relationship between Ricaniidae and other families of Fulgoroidea needs to be further explored. The morphological definitions of the two biggest genera, Pochazia Amyot \& Serville, 1843 and Ricania Germar, 1818 (the type genus of Ricaniidae) remain controversial. In this study, mitogenomes of five representatives in these two genera were decoded using the next-generation sequence method and genome assembly. Results showed that their complete mitogenomes are circular DNA molecules with 15,457 to 16,411 bp. All protein-coding genes (PCGs) begin with the start codon ATN, GTG or TTG and end with TAA, TAG, an incomplete stop codon single T or an incomplete stop codon single A. A lost DHU arm was discovered in the trnS gene of the five mitogenomes and the $\operatorname{trn} V$ gene within Pochazia confusa, Pochazia guttifera and Ricania simulans. The remnant tRNAs folded into cloverleaf structures. The sliding window, genetic distance, and $\mathrm{Ka} / \mathrm{Ks}$ analyses indicated that the cox 1 gene is the slowest evolving and is relatively conserved. The phylogenetic tree topologies support $($ Delphacidae $+((($ Issidae $+($ Lophopidae + Caliscelidae $))+($ Flatidae + Ricaniidae $))+($ Achilidae + $($ Dictyopharidae + Fulgoridae) $))$ ) as the best topology, as recognized by both PhyloBayes, RAxML and MrBayes based on four data sets (PCG, PCGRNA, PCG12, PCG12RNA). The monophyly of Ricaniidae and the sister group status of two families Flatidae and Ricaniidae are supported, but all analyses failed to support the monophyly of Pochazia and Ricania. The diagnoses between these two genera cannot be resolved until more evidence is acquired.
\end{abstract}

Keywords: Fulgoroidea; Ricaniidae; phylogeny; mitogenomes 


\section{Introduction}

Ricaniidae Amyot \& Audinet-Serville, 1843 is an economically important family in the superfamily Fulgoroidea. It is comprised of 442 species (3.2\% of the Fulgoromorpha) with 69 genera (2.8\% of the Fulgoromorpha) divided into two subfamilies [1]. This family of planthoppers is distributed throughout the warm temperate and tropical regions of the world. They are associated with both herbaceous and woody plants and have adapted to various habitats ranging from rainforests to semideserts.

Some phytophagous members of this family are major agricultural pests. For example, Ricania speculum (Walker, 1851), Pochazia shantungensis (Chou \& Lu, 1977) and Orosanga japonica (Melichar, 1898) are major agricultural pests having a very wide range of hosts. Their damage, caused by sap suction and by egg-laying, may lead to the withering of the host tissues [2].

Research into the phylogenetic relationships of these planthopper families has been attempted in recent years, based either on morphological characters [3-6] or on molecular data [7-9]. However, their taxonomic relationships remain unclear.

For Ricaniidae, it has been clustered in one clade with Eurybrachidae and Lophopidae [3-5], or with Flatidae [6,9], or with Eurybrachidae [7], or with Caliscelidae [8]. The relationships between Ricaniidae and other families of Fulgoroidea need to be further explored.

The genera Ricania Germar, 1818 and Pochazia Amyot \& Audinet-Serville, 1843 have the most abundant species (Ricania 82 spp., Pochazia 44 spp.) within the family Ricaniidae. The morphological definitions of both genera are unclear and based on external characters, mainly in the size of the forewing, the apical angle, and the ratio of apical margin and claval suture. In Pochazia the forewing is large, the apical angle is prominent, and the apical margin is longer than the claval suture. In Ricania, the forewing is relatively small, the apical angle broadly rounded, and the apical margin is nearly as long as the claval suture [10-12].

For example, the assignment of Ricania shantungensis Chou \& Lu, 1977 has been controversial in recent years. It was transferred to Pochazia by Rahman et al. (2012) [12], but this treatment was rejected by Kwon et al. (2017) [13], Baek et al. (2020) [14] and Park and Jung (2020) [15].

Both genera (in recent definition and composition) are non-monophyletic groups (Stroiński, per. com.). Further research into the scope and definition of these taxa is needed.

Up to now, only three Ricaniid species mitogenomes (Pochazia shantungensis, Ricania speculum and Ricania marginalis (Walker, 1851)) have been sequenced [16-18]. In this study, the mitochondrial genomes of five Ricaniid species were sequenced and assembled (Pochazia confusa Distant, 1906; Pochazia discreta Melichar, 1898; Pochazia guttifera Walker, 1851; Ricania simulans (Walker, 1851) and Ricania fumosa (Walker, 1851)). This study aims to clarify the relationship of Ricaniidae with other families of Fulgoroidea and also provide evidence to clarify the differences between these two related genera for species attribution.

\section{Materials and Methods}

\subsection{Sample Preparation and DNA Extraction}

Adult specimens of five Ricaniid species were studied. Pochazia confusa (Figure 1A), Pochazia discreta (Figure 1B), Pochazia guttifera (Figure 1C), and Ricania fumosa (Figure 1E) were collected in Guangdong Province (Table S1). Ricania simulans (Figure 1D) was collected in Hunan Province (Table S1). All specimens were preserved in $100 \%$ ethanol at $-20^{\circ} \mathrm{C}$ to allow DNA extraction. All specimens were identified by the first author before DNA extraction. The genomic DNA was extracted using the DNeasy DNA Extraction Kit (Qiagen). 

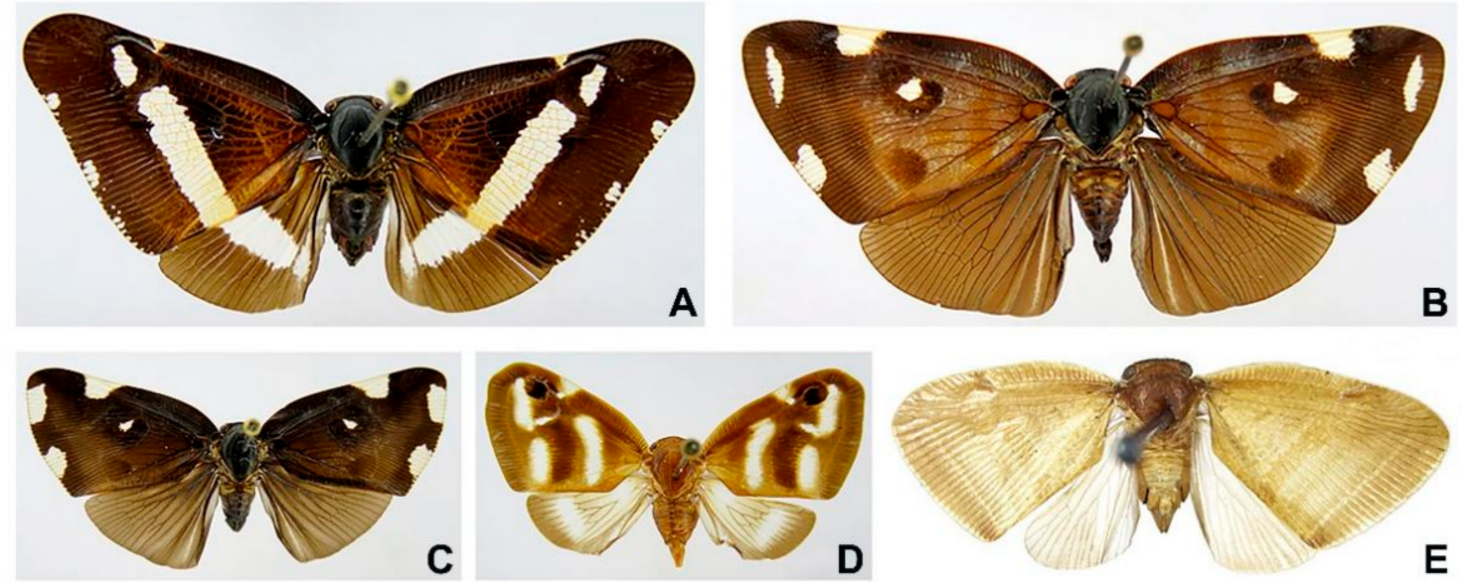

Figure 1. Photo plate of five Ricaniidae specimens. (A) Pochazia confusa, (B) Pochazia discreta, (C) Pochazia guttifera, (D) Ricania simulans, (E) Ricania fumosa.

\subsection{Sequencing, Assembly, Annotation, and Analysis}

The whole genomic DNA for each of the five Ricaniid species was sequenced once by the next-generation sequence method on the Illumina NovaSeq platform. Results were aligned with Sanger sequencing results to ensure accuracy. The quality-trimming and assembly of the paired reads were checked by Geneious v 11.0.2 with default parameters [19], employing the closely related Ricania speculum (Hemiptera: Ricaniidae; MT834932) [17] as a reference sequence.

The annotation of genomic features was conducted using Geneious v 11.0.2, with Ricania speculum and Pochazia shantungensis as references. The open reading frames (ORFs) Finder was created based on the invertebrate mitochondrial genetic codes. The mitogenomic maps of these five species were visualized using the CGview Server [20]. The secondary structures of tRNAs were predicted by the MITOS Web Server [21]. According to the predicted results, the tRNAs of the five species were edited using Adobe Illustrator CS2020.

PhyloSuite v 1.2.2 calculated base composition and RSCU (relative synonymous codon usage) [22]. Tandem Repeats Finder Online server was employed to obtain the tandem repeats in the control region [23]. The sliding window analysis was performed with DnaSP v 6.0 based on concatenated alignments of PCGs and rRNA genes among eight Ricaniidae mitogenomes [24]. The average non-synonymous (Ka)/synonymous (Ks) substitution rates and average genetic distances were estimated via DnaSP v 6.0 and MEGA-X based on each PCG of the eight Ricaniidae mitogenomes, respectively [25]. The mitogenomes of Pochazia confusa, Pochazia discreta, Pochazia guttifera, Ricania simulans and Ricania fumosa were uploaded to GenBank with accession numbers MZ617458, MZ673797, MZ617457, MZ617459, and MZ617460, respectively (Table 1).

\subsection{Mitogenome Sequence Alignment and Analyses of Sequence Heterogeneity}

Five newly sequenced Ricaniidae mitogenomes and a total of 44 known mitogenome sequences of Fulgoroidea were selected as ingroups, including 3 species of Ricaniidae, 10 species of Delphacidae, 5 species of Achilidae, 1 species of Dictyopharidae, 14 species of Fulgoridae, 2 species of Issidae, 1 species of Lophopidae, 4 species of Caliscelidae, and 4 species of Flatidae. Populicerus populi (Linnaeus) (Cicadellidae), Empoascanara gracilis Dworakowska, 1992 (Cicadellidae), Stictocephala bisonia Kopp \& Yonke, 1977 (Membracidae), and Tricentrus brunneus Funkhouser, 1918 (Membracidae) were selected as outgroups (Table 1). 
Table 1. Taxa used in this study.

\begin{tabular}{|c|c|c|c|}
\hline Figure Taxon & Species & GenBank Number & References \\
\hline \multicolumn{4}{|l|}{ Outgroups } \\
\hline \multirow[t]{2}{*}{ Cicadellidae } & Empoascanara gracilis Dworakowska & MT576649 & Unpublished \\
\hline & Populicerus populi (Linnaeus) & MH492318 & Wang et al., (2018) \\
\hline \multirow[t]{2}{*}{ Membracidae } & Stictocephala bisonia Kopp \& Yonke & MW342606 & Yu et al., (2021) \\
\hline & Tricentrus brunneus Funkhouser & NC_044708 & Hu et al., (2019) \\
\hline \multicolumn{4}{|l|}{ Ingroup } \\
\hline \multirow[t]{10}{*}{ Delphacidae } & Ugyops sp. & МH352481 & Yu \& Liang (2018) \\
\hline & Bambusiphaga furca Huang \& Tian & NC_052689 & Huang et al., (2020) \\
\hline & Bambusiphaga taibaishana Qin & NC_052690 & Huang et al., (2020) \\
\hline & Changeondelphax velitchkovskyi (Melichar) & NC_037181 & Huang \& Qin (2017) \\
\hline & Peregrinus maidis (Ashmead) & NC_037182 & Huang \& Qin (2017) \\
\hline & Sogatella furcifera (Horváth) & КС512915 & Zhang et al., (2014) \\
\hline & Laodelphax striatella (Fallén) & JX880068 & Zhang et al., (2013) \\
\hline & Nilaparvata bakeri (Muir) & NC_033388 & Unpublished \\
\hline & Nilaparvata lugens (Stål) & NC_021748 & Unpublished \\
\hline & Nilaparvata muiri China & JN563998 & Lv et al., (2015) \\
\hline \multirow[t]{5}{*}{ Achilidae } & Achilidae sp. & МH324929 & Xu et al., (2019) \\
\hline & Betatropis formosana Matsumura & MH324927 & Xu et al., (2019) \\
\hline & Plectoderini sp. & MH324930 & Xu et al., (2019) \\
\hline & Paracatonidia sp. & МH324931 & Xu et al., (2019) \\
\hline & Magadhaideus sp. & MH324928 & Xu et al., (2019) \\
\hline Dictyopharidae & Orthopagus splendens (Germar) & MW441850 & Unpublished \\
\hline \multirow[t]{14}{*}{ Fulgoridae } & Aphaena amabilis (Hope) & NC_045075 & Wang et al., (2019) \\
\hline & Aphaena discolor nigrotibiata Schmidt & MN025523 & Wang et al., (2019) \\
\hline & Lycorma delicatula (White) & MN607209 & Unpublished \\
\hline & Lycorma meliae Kato & MT079725 & Du et al., (2021) \\
\hline & Penthicodes atomaria (Weber) & MW662662 & Wang et al., (2021) \\
\hline & Penthicodes variegata (Guérin-Méneville) & MW662664 & Wang et al., (2021) \\
\hline & Penthicodes caja (Walker) & MW662663 & Wang et al., (2021) \\
\hline & Limois sp. & MW662660 & Wang et al., (2021) \\
\hline & Neoalcathous huangshanana Wang \& Huang & MW662661 & Wang et al., (2021) \\
\hline & Dichoptera sp. & MW662659 & Wang et al., (2021) \\
\hline & Pyrops candelaria (Linné) & MW355618 & Duan \& Hu (2021) \\
\hline & Pyrops clavatus (Westwood) & MW662665 & Wang et al., (2021) \\
\hline & Pyrops lathburii (Kirby) & MW662666 & Wang et al., (2021) \\
\hline & Pyrops spinolae (Westwood) & MW662667 & Wang et al., (2021) \\
\hline \multirow[t]{2}{*}{ Issidae } & Sivaloka damnosus (Chou \& Lu) & NC_014286 & Song et al., (2010) \\
\hline & Hemisphaerius rufovarius Walker & MT210096 & Yang et al., (2020) \\
\hline Lophopidae & Lophops carinata (Kirby) & NC_053739 & Xu \& Chen (2021) \\
\hline \multirow[t]{4}{*}{ Caliscelidae } & Bambusicaliscelis fanjingensis Chen \& Zhang & MW'281859 & Gong et al., (2021) \\
\hline & Bambusicaliscelis flavus Chen \& Gong & MW281858 & Gong et al., (2021) \\
\hline & Youtuus erythrus Gong, Yang \& Chen & MW281861 & Gong et al., (2021) \\
\hline & Youtuus strigatus Gong, Yang \& Chen & MW281860 & Gong et al., (2021) \\
\hline \multirow[t]{4}{*}{ Flatidae } & Cromna sinensis (Walker) & MW872012 & Ai et al., (2021) \\
\hline & Cerynia lineola Melichar & MW872011 & Ai et al., (2021) \\
\hline & Geisha distinctissima (Walker) & FJ230961 & Song \& Liang (2009) \\
\hline & Zecheuna tonkinensis Zia & MW872013 & Ai et al., (2021) \\
\hline \multirow[t]{8}{*}{ Ricaniidae } & Pochazia confusa Distant & MZ617458 & This study \\
\hline & Pochazia discreta Melichar & MZ673797 & This study \\
\hline & Pochazia guttifera Walker & MZ617457 & This study \\
\hline & Pochazia shantungensis (Chou \& Lu) & MT898421 & Kang et al., (2020) \\
\hline & Ricania speculum (Walker) & MT834932 & Lee et al., (2020) \\
\hline & Ricania fumosa (Walker) & MZ617460 & This study \\
\hline & Ricania marginalis (Walker) & NC_019597 & Song et al., (2012) \\
\hline & Ricania simulans (Walker) & MZ617459 & This study \\
\hline
\end{tabular}

The extraction of 13 PCGs, 2 rRNAs, and amino acid (PCG-AA) was implemented by PhyloSuite v 1.2.2 [22]. All 13 PCGs were aligned with the G-INS-i algorithm and codon 
alignment mode in MAFFT 7 [26]. Alignments of two rRNAs were produced with the Q-INS-i algorithm in the MAFFT 7. Alignments of PCG-AA were produced using the G-INS-i algorithm in the MAFFT 7. We used Gblocks v 0.91b [27] to remove all gaps and poorly matched aligned sites of 13 PCGs, 2 rRNAs, and PCG-AA. The concatenated data of all alignments were performed by PhyloSuite v 1.2.2. Five various data sets were generated to reconstruct the phylogeny: (1) PCG matrix (all codon positions of PCGs), (2) PCGRNA matrix (all codon positions of PCGs and 2 rRNAs), (3) PCG12 matrix (removal of third codon position of PCGs), (4) PCG12RNA matrix (removal of third codon position of PCGs and 2 rRNAs) and (5) PCG-AA matrix (amino acid sequences of PCGs).

The sequence divergence heterogeneity of five data sets was assessed using AliGROOVE [28] with the default sliding window size. The gaps in the nucleotide data set were treated as ambiguity, and a BLOSUM62 matrix was used for a default amino acid substitution matrix.

\subsection{Phylogenetic Analyses}

The phylogenetic analyses under site-homogeneous models were reconstructed by Bayesian Inference (BI) and Maximum Likelihood (ML) methods. The optimal partitions and best models for both ML and BI trees were selected by PartitionFinder 2.1.1 (Tables S9 and S10) [29], with greedy algorithm and BIC criterion. ML analyses were conducted in IQ-TREE 1.6.5 [30] using 1000 replicates of ultrafast bootstraps. BI analyses were performed using MrBayes 3.2.6 [31], each run for 10,000,000 generations, with sampling every 100 generations. A consensus tree was calculated from the remaining samples after burn-in of the first $25 \%$ of trees.

We used PhyloBayes MPI v1.5a on CIPRES [32] to reconstruct Bayesian inferences with a site-heterogeneous CAT+GTR model and the default parameter. Two independent chains proceeded simultaneously until the runs were converged (maxdiff was $<0.1$ ). The initial $25 \%$ of the two chains were discarded as burn-in and a consensus tree was generated from the remaining samples.

\section{Results}

\subsection{Mitogenome Organization and Base Composition}

The circular complete mitogenomes of Pochazia confusa, Pochazia discreta, Pochazia guttifera, Ricania simulans and Ricania fumosa were 16,121,16,411,16,153, 15,457 and 16,016 bp in length, respectively (Figure 2). The total length of the complete mitogenomes is associated with the variation in length of the control region. The five newly sequenced mitogenomes comprised the typical 37 genes: 13 protein-coding genes (PCGs), 22 transfer RNA genes (tRNAs), two ribosomal RNA genes (rRNAs), and an A+T-rich region (control region). Gene arrangement was consistent with other planthopper mitogenomes. The majority strand (J-strand) encoded 9 PCGs and 14 tRNAs, while the remaining genes were encoded on the minority strand (N-strand) (Tables S2-S6).

The nucleotide composition (Table S7) for Pochazia confusa was: A $=48.4 \%, \mathrm{C}=14.3 \%$, $\mathrm{G}=9.0 \%$, and $\mathrm{T}=28.3 \%$; for Pochazia discreta: $\mathrm{A}=47.6 \%, \mathrm{C}=16.6 \%, \mathrm{G}=9.7 \%$, and $\mathrm{T}=26.0 \%$; for Pochazia guttifera: $\mathrm{A}=47.9 \%, \mathrm{C}=15.6 \%, \mathrm{G}=9.4 \%$, and $\mathrm{T}=27.2 \%$; for Ricania simulans: $\mathrm{A}=47.6 \%, \mathrm{C}=13.8 \%, \mathrm{G}=8.8 \%$, and $\mathrm{T}=29.7 \%$; and for Ricania fumosa: $\mathrm{A}=48.1 \%$, $\mathrm{C}=14.7 \%, \mathrm{G}=9.3 \%$, and $\mathrm{T}=28.0 \%$.

The whole mitogenomes of five Ricaniid species presented a positive AT skew and negative GC skew. The high A+T content was observed in five Ricaniid mitogenomes with $76.7,73.6,75.1,77.3$, and $76.1 \%$, respectively (Table S7). This situation has also been observed in other planthopper species.

\subsection{Protein-Coding Genes and Codon Usage}

The total length of PCGs ranged from 10,914 bp (Pochazia confusa) to 10,956 bp (Ricania fumosa) in size among these five newly sequenced Ricaniidae mitogenomes. Comparing the PCGs in the five Ricaniid mitogenomes, the A+T contents of Pochazia confusa, Pochazia 
discreta, Pochazia guttifera, Ricania simulans, and Ricania fumosa were 75.6, 72.9, 73.3, 76.4, and $75.6 \%$, respectively. All PCGs represented a negative AT skew and GC skew. The A+T content of the third codon was highest, while that of the second codon was lowest. The AT skew and GC skew of the first codon position was highest (Table S7).

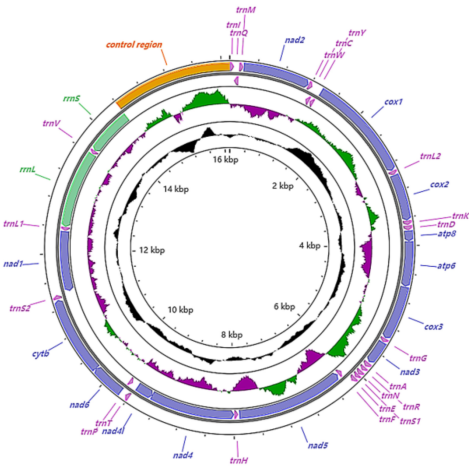

Pochazia confusa Length: $16121 \mathrm{bp}$

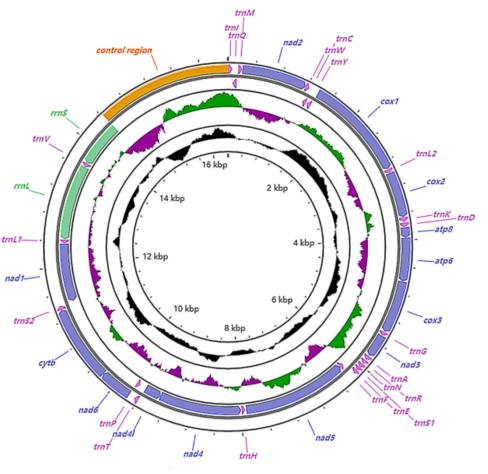

Pochazia discreta Length: $16411 \mathrm{bp}$

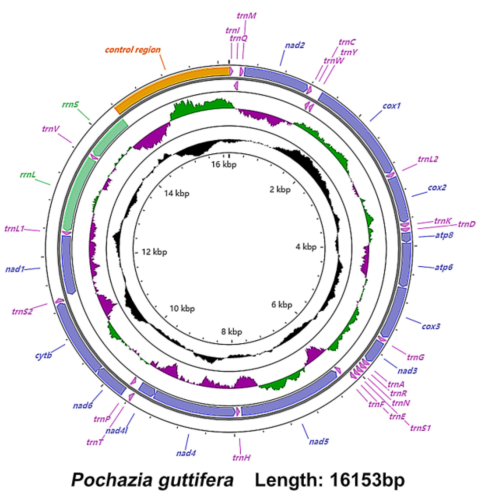

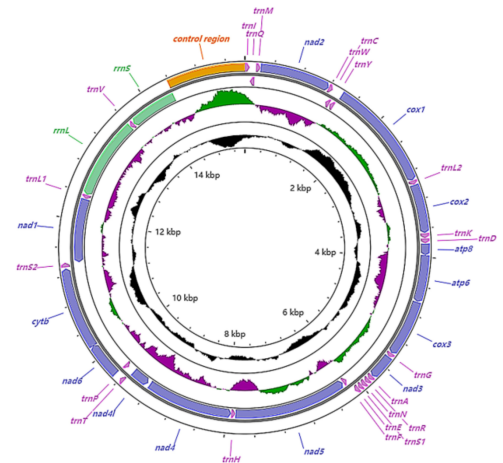

Ricania simulans Length: $15457 \mathrm{bp}$

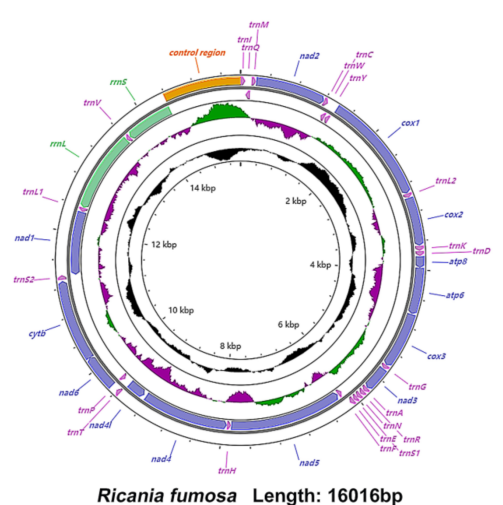

Ricania fumosa Length: $16016 \mathrm{bp}$

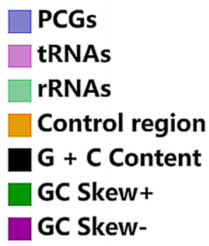

Figure 2. The mitochondrial genome of Pochazia confusa, Pochazia discreta, Pochazia guttifera, Ricania simulans and Ricania fumosa.

In the Ricaniid mitogenomes, most PCGs initiated with the typical start codon ATN (ATA/T/G/C), with an exception for the nad5 gene in Ricania simulans and Ricania fumosa that began with GTG and TTG, respectively. Correspondingly, most PCGs terminated with a TAA/TAG codon, but the cox2, atp6, and nad4 genes ended with a single T, except for atp6 in Ricania marginalis using TAG as the stop codon. The nad1 gene in Ricania speculum, Pochazia shantungensis, and Ricania marginalis ended respectively with a single A, single $\mathrm{A}$, and TAA, whereas the five newly sequenced mitochondrial genomes terminated with $\mathrm{T}$ (Table S8). A large segment poly (A) appeared in nad4 and nad5 genes of five newly sequenced Ricaniidae mitogenomes.

The RSCU (relative synonymous codon usage) of eight Ricaniidae mitogenomes is shown in Figure 3. Phe (UUU), Ile (AUU), Met (AUA), Ser (UCA), and Leu (UUA) were 
observed to be the most frequently used codons. The amino acid compositions were mostly A or $\mathrm{U}$, indicating the strong AT bias in the whole mitochondrial genome. This codon usage pattern across these eight Ricaniidae mitogenomes was consistent with other planthoppers. However, the codon Thr (ACG) was not found in Ricania speculum and the codons Arg (CGG) and Ala (GCG) were not observed in Pochazia confusa.
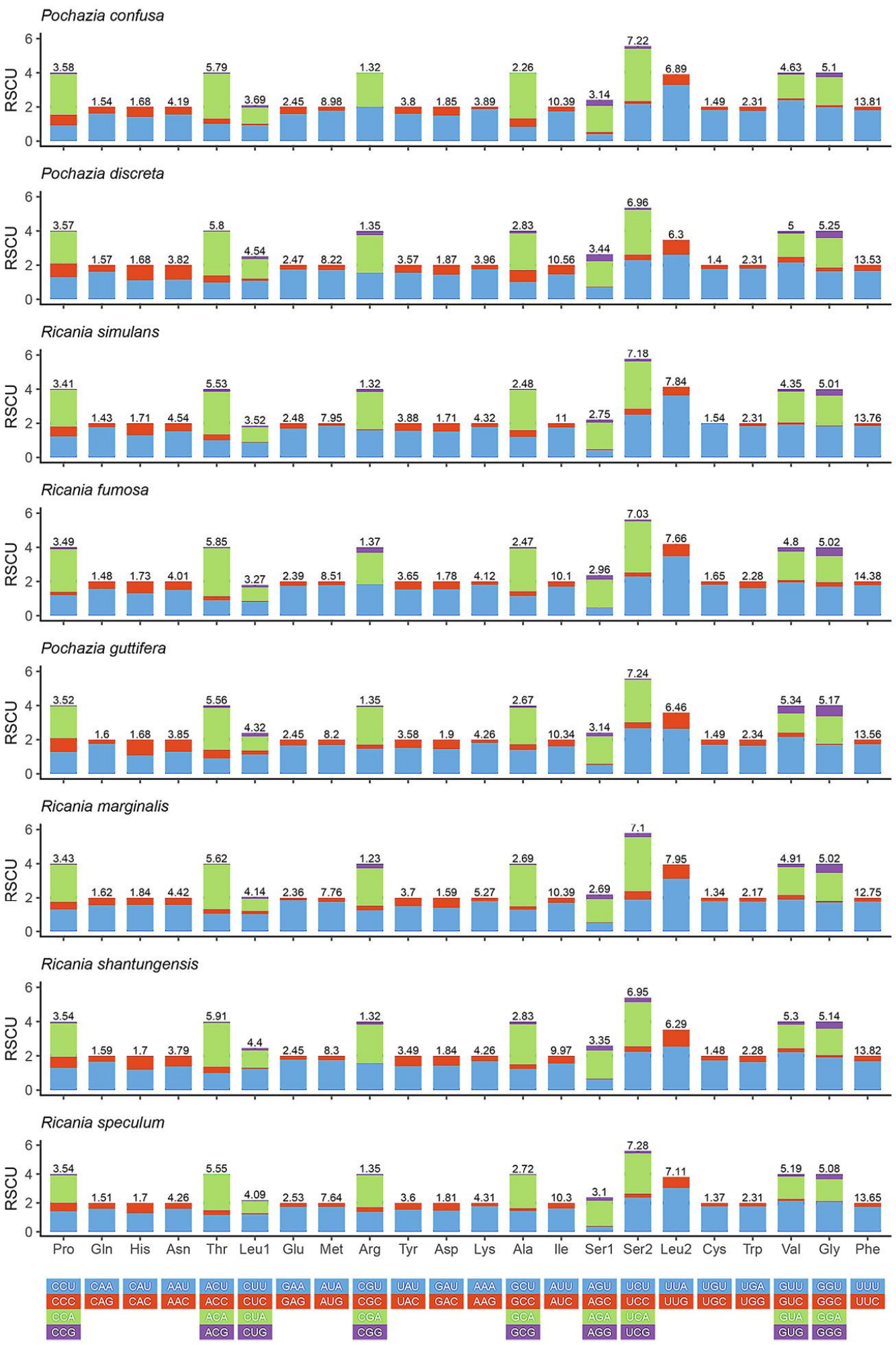

Figure 3. Relative synonymous codon usage (RSCU) of the mitogenomes of eight Ricaniidae species. 


\subsection{Transfer and Ribosomal RNA Genes}

The 22 tRNAs were located scattered throughout the whole mitogenome in the five newly sequenced Ricaniid species (Figure 2). Their total lengths ranged in size from $1406 \mathrm{bp}$ (Ricania simulans) to $1424 \mathrm{bp}$ (Pochazia discreta). The tRNAs presented a positive AT skew and GC skew in the five Ricaniid mitogenomes. These tRNAs with a heavy AT nucleotide bias reached 76.0, 74.8, 75.5, 76.1, and 76.1\% in Pochazia confusa, Pochazia discreta, Pochazia guttifera, Ricania simulans, and Ricania fumosa, respectively (Table S7); this has also been found in other sequenced planthoppers.

The loss of the DHU arm was found in the trnS gene of the five Ricaniid mitogenomes and the trnV gene within Pochazia confusa, Pochazia guttifera, and Ricania simulans. The remnant tRNAs folded into clover-leaf structures. All five newly sequenced mitogenomes had an unpaired base in the anticodon stem of the $\operatorname{trnL} 2$ and $t r n R$ genes. In addition, six types of unmatched base pairs, G-U, U-U, A-A, G-A, A-C, and U-C, were found in the secondary structure of tRNAs in these five Ricaniid mitogenomes. The total number of unmatched base pairs were 30 in Pochazia confusa, 29 in Pochazia discreta, 28 in Pochazia guttifera, 32 in Ricania simulans and 28 in Ricania fumosa (Figures S1-S5).

The total lengths of two rRNAs ranged from $1930 \mathrm{bp}$ (Pochazia confusa) to $1941 \mathrm{bp}$ (Pochazia guttifera) in size. The rrnL gene, located between trnL1 and trnV, was $1206 \mathrm{bp}$ in Pochazia confusa, 1211 bp in Pochazia discreta, 1217 bp in Pochazia guttifera, 1209 bp in Ricania simulans, and 1212 bp in Ricania fumosa. The rrnS gene, flanked by $t r n V$ and the control region, was 724 bp in Pochazia confusa, 722 bp in Pochazia discreta, 724 bp in Pochazia guttifera, $722 \mathrm{bp}$ in Ricania simulans, and $722 \mathrm{bp}$ in Ricania fumosa. The two rRNA in these five mitogenomes showed a negative AT skew and positive GC skew. In addition, Pochazia confusa (79.2\%), Pochazia discreta (77.3\%), Pochazia guttifera (77.3\%), Ricania simulans (78.6\%), and Ricania fumosa (77.9\%) represented heavy A+T content (Tables S2-S7).

\subsection{The Control Region}

The control region, encoded on the J-strand, was located between $r r n S$ and $\operatorname{trnI}$ (Figure 2). The control region of all five newly sequenced mitogenomes represented a positive AT skew and negative GC skew, except Ricania simulans, which presented a negative AT skew and positive GC skew. The total length of this region was $1721 \mathrm{bp}$ in Pochazia confusa, 1985 bp in Pochazia discreta, 1763 bp in Pochazia guttifera, 1078 bp in Ricania simulans, and $1652 \mathrm{bp}$ in Ricania fumosa (Tables S2-S7). Comparing tandem repeat regions of eight Ricaniid mitogenomes, the results showed that one repeat region was detected in Pochazia confusa, Pochazia discreta, Pochazia guttifera, Pochazia shantungensis, and Ricania simulans, and three repeat regions were present in Ricania fumosa. In addition, the control region of Ricania speculum and Ricania marginalis had two tandem repeat regions with a second repeat unit of "ATAATATAT". We also found poly (A) or poly (T) in some Ricaniid species (Figure 4).

\subsection{Nucleotide Diversity and Genetic Distance}

Nucleotide diversity of 13 PCGs and 2 rRNAs is shown among eight Ricaniidae species in Figure 5. The value of nucleotide diversity ranged from 0.097 ( $r r n S)$ to 0.247 (nad2). The result indicated that nad6 $(\mathrm{Pi}=0.216)$ and nad2 $(\mathrm{Pi}=0.247)$ presented higher nucleotide diversity, whereas nad4 $(\mathrm{Pi}=0.129)$, nad5 $(\mathrm{Pi}=0.137)$, and cox1 $(\mathrm{Pi}=0.144)$ exhibited a relatively low nucleotide diversity. Two rRNAs $(r r n S(P i=0.097)$ and $r r n L(P i=0.126))$ were highly conserved genes (Figure 5).

The average Ka/Ks rates of 13 PCGs were calculated among eight Ricaniidae species with Cromna sinensis as the reference sequence. The $\mathrm{Ka} / \mathrm{Ks}$ values were less than 1 , representing purifying selection in each gene. The Ka/Ks ratio of $\operatorname{cox} 1(\omega=0.088)$ exhibited the strongest purifying selection, while atp $8(\omega=0.536)$ exhibited the weakest purifying selection. Furthermore, the average genetic distances among eight Ricaniidae species with Cromna sinensis as the reference sequence showed that nad2 (0.428) was evolving comparatively fast, while cox1 (0.198) was relatively slower (Figure 6). 
Pochazia confusa

rrnS $\quad$ 610bp

Pochazia discreta

$1985 \mathrm{bp}$

\begin{tabular}{|c|c|c|c|c|c|}
\hline$r r n S$ & $964 b p$ & 1 & 2 & $239 b p$ & $t r n I$ \\
\hline
\end{tabular}

Pochazia guttifera

1763bp

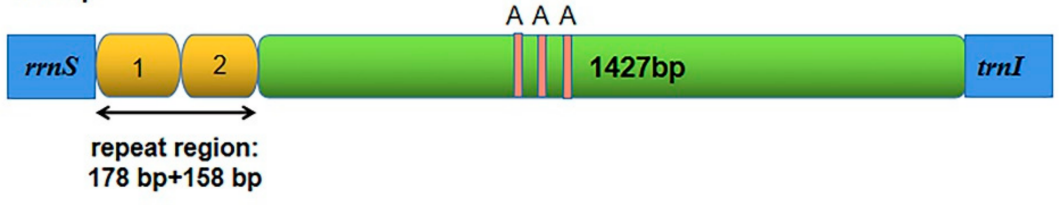

Pochazia shantungensis

1363bp

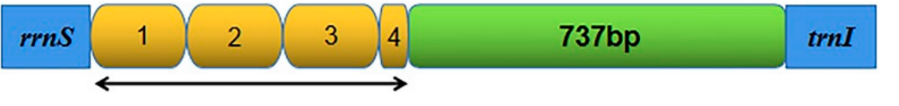

repeat region:

$3 \times(200 b p)+26 b p$

Ricania marginalis

1324bp

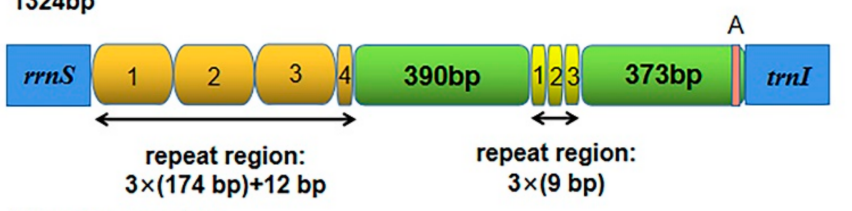

Ricania speculum

1172bp

A

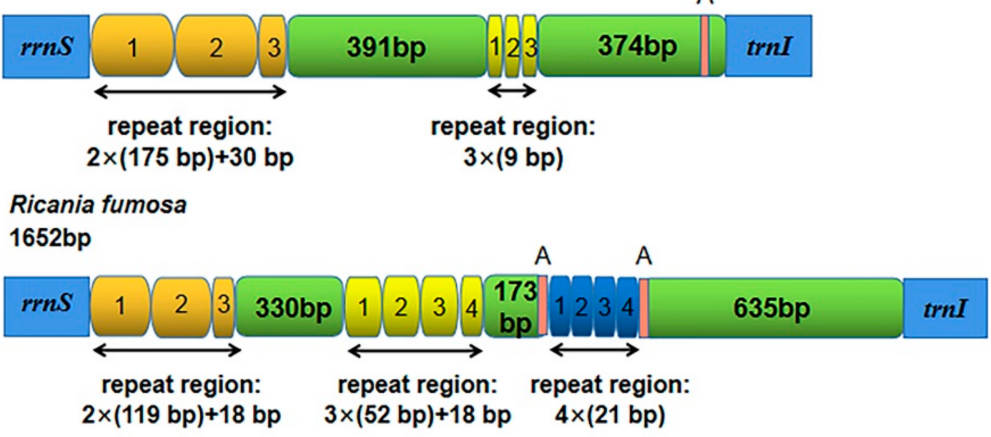

Ricania simulans

1078bp

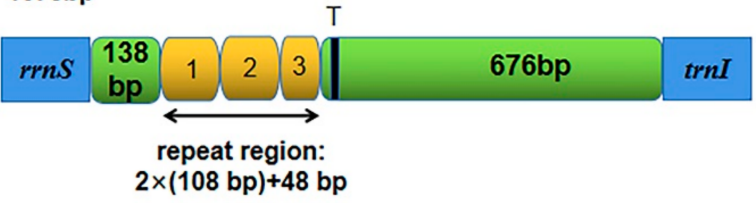

Figure 4. Organization of the control regions in the eight Ricaniidae mitogenomes. The chrome yellow, yellow ochre, and blue rounded rectangles indicate the tandem repeats. Non-repeat regions are represented by a green rounded rectangle. The red and black blocks are the structures of poly (A) or poly (T). 


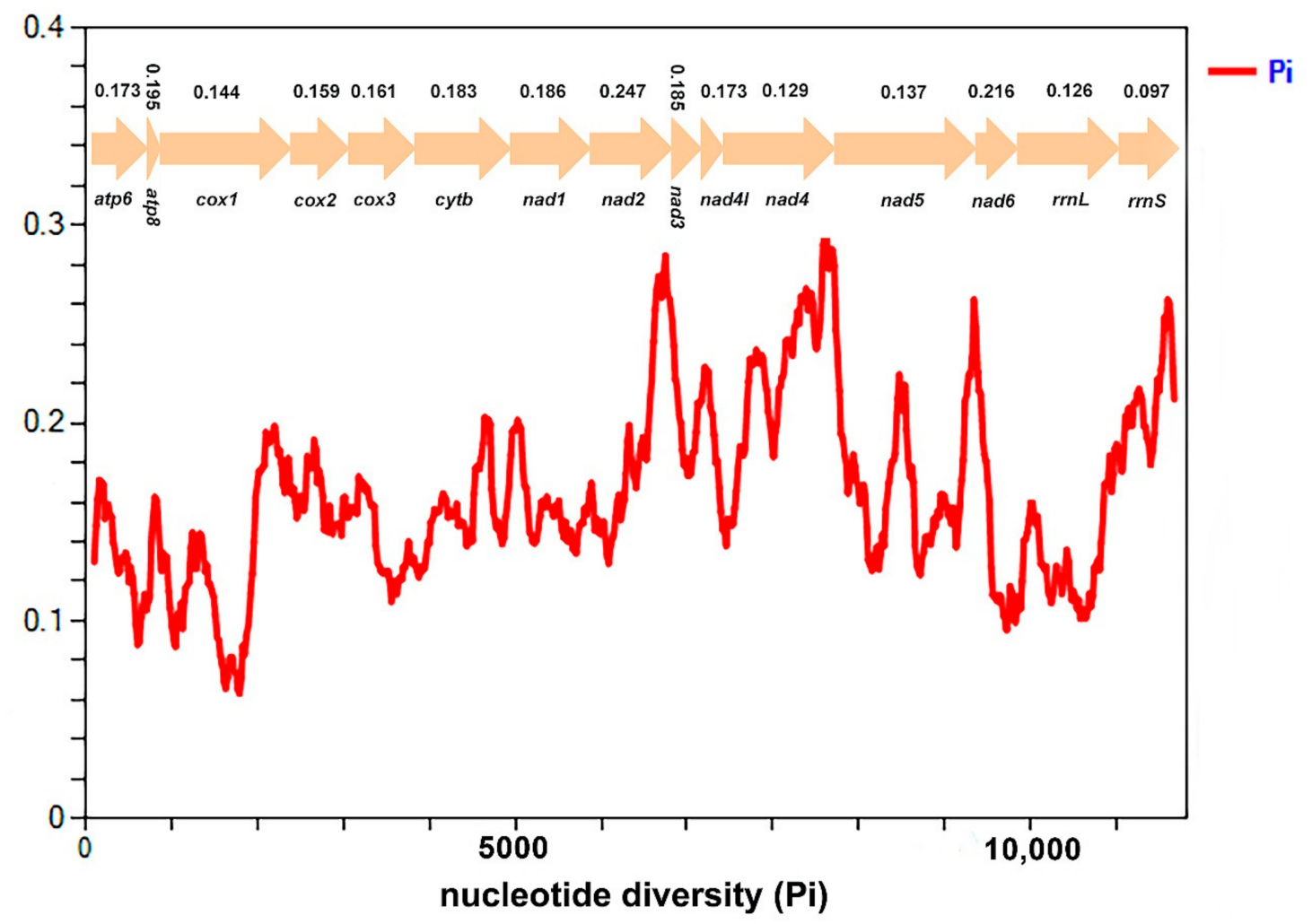

Figure 5. Sliding window analysis of 13 PCGs and 2 rRNAs based on eight Ricaniidae species. The red line shows the value of nucleotide diversity $\mathrm{Pi}$ ( window size $=200 \mathrm{bp}$, step size $=20 \mathrm{bp}$ ). The Pi value for each gene is shown in the graph.

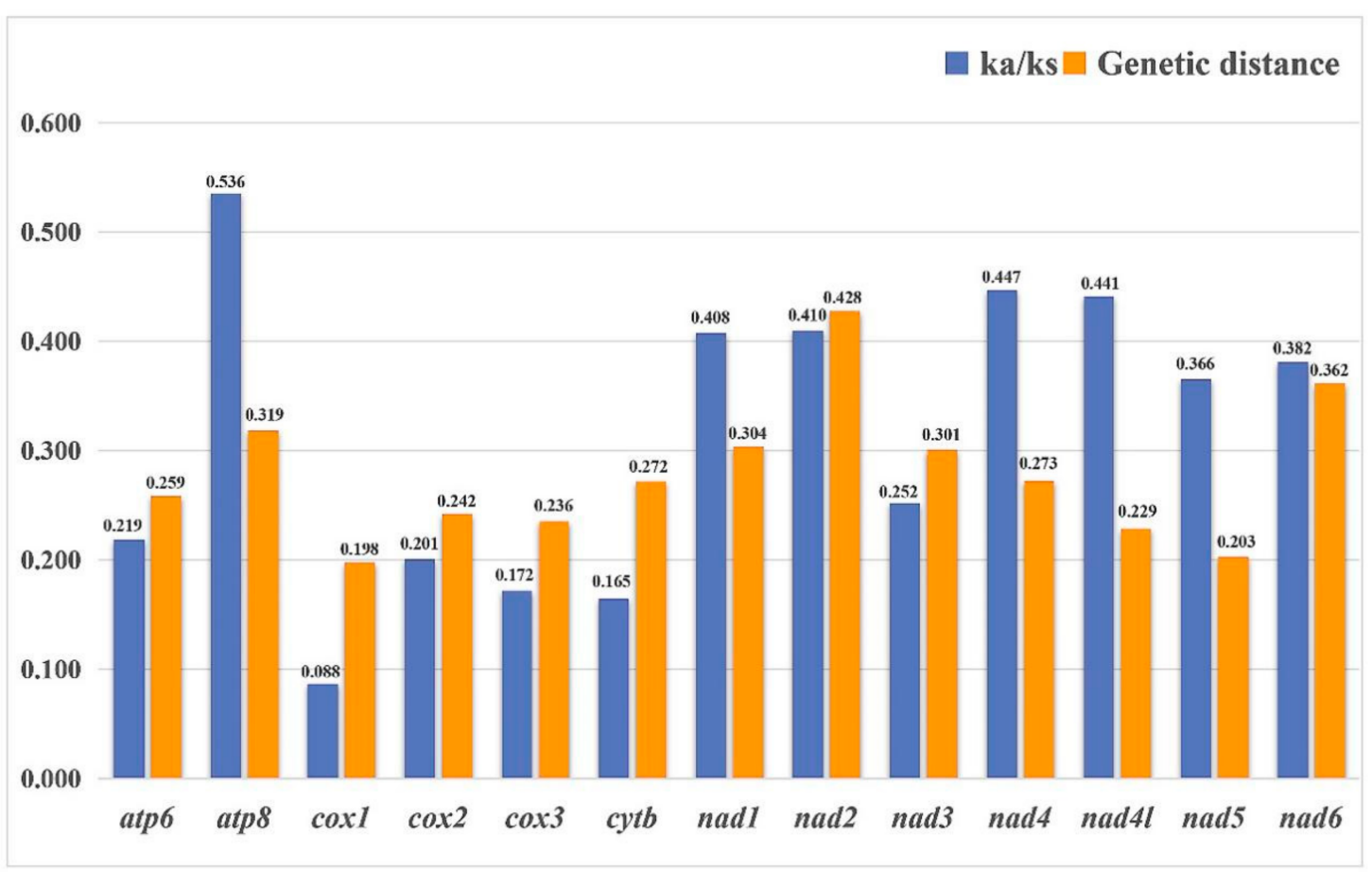

Figure 6. Ka/Ks rates and genetic distance (on average) of 13 PCGs were calculated among eight Ricaniidae species, using Cromna sinensis as a reference sequence. 
According to this assessment, heterogeneity was higher in pairwise sequence comparisons with the Delphacidae, whereas heterogeneity was lower among other planthoppers. Results also indicated that PCG-AA had lower heterogeneity than other data sets. Comparing sequence composition heterogeneity of four data sets (PCG, PCGRNA, PCG12 and PCG12RNA), we found the third codon of PCGs had higher heterogeneity (Figure 7).
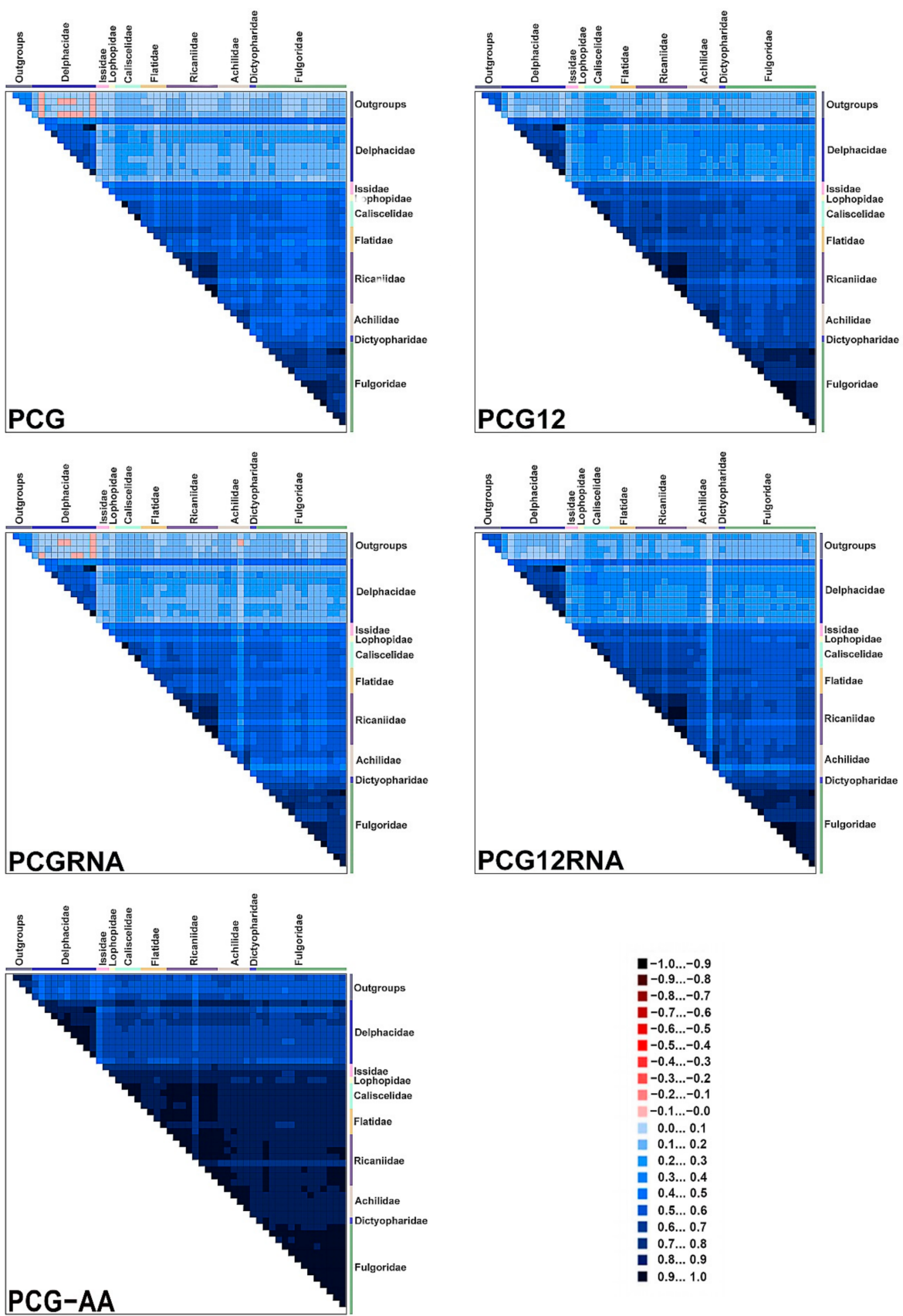

Figure 7. Heterogeneous sequence divergence for five different data sets with 53 taxa. Each colored square represents the pairwise Aliscore values. The scores range from -1 , indicating a great difference in sequence composition (red coloring), to +1 , indicating similarity to other sequence composition (blue coloring). The taxon names of different families are represented by color-coded boxes, listed on top and on the right side of the matrix.

\subsection{Phylogenetic Analyses}

To establish the evolutionary relationships within Ricaniidae species, the complete mitogenomes of 44 other planthoppers species were downloaded from GenBank (Table 1). 
The tree topologies of the PhyloBayes, ML, and BI analyses were identical based on four data sets (PCG, PCGRNA, PCG12, PCG12RNA). These phylogenetic trees were (Delphacidae $+((($ Issidae $+($ Lophopidae + Caliscelidae $))+($ Flatidae + Ricaniidae $))+($ Achilidae $+($ Dictyopharidae + Fulgoridae) $)))($ Figure 8 and Figure S6). Two tree topologies based on PCG-AA were different from the above results. The tree topologies with ML and BI analyses were (Delphacidae $+(($ Dictyopharidae + Fulgoridae $)+($ Achilidae $+($ (Lophopidae + Caliscelidae $)+($ Issidae $+($ Flatidae + Ricaniidae $))))))($ Figure S7) . The tree topologies using PhyloBayes analyses were (Delphacidae + (Achilidae $+(($ Dictyopharidae + Fulgoridae $)$ $+($ Lophopidae + ((Issidae + Caliscelidae $)+($ Flatidae + Ricaniidae $)))))$ (Figure S8). Compared to PhyloBayes, RAxML and MrBayes, a phylogeny of (Delphacidae + (((Issidae + $($ Lophopidae + Caliscelidae $))+($ Flatidae + Ricaniidae $))+($ Achilidae $+($ Dictyopharidae + Fulgoridae)))) was the best topology. In most results, Lophopidae and Caliscelidae were recovered as a sister lineage. All results supported the family Delphacidae as the most ancient lineage with maximum values (PP/BS $=1 / 100)$. In addition, the Ricaniidae were placed as a sister group to Flatidae with moderate nodal values in all results (BS > 94; PP > 0.78) except ML analysis of PCG-AA had a weak nodal value ( $B S=55)$.

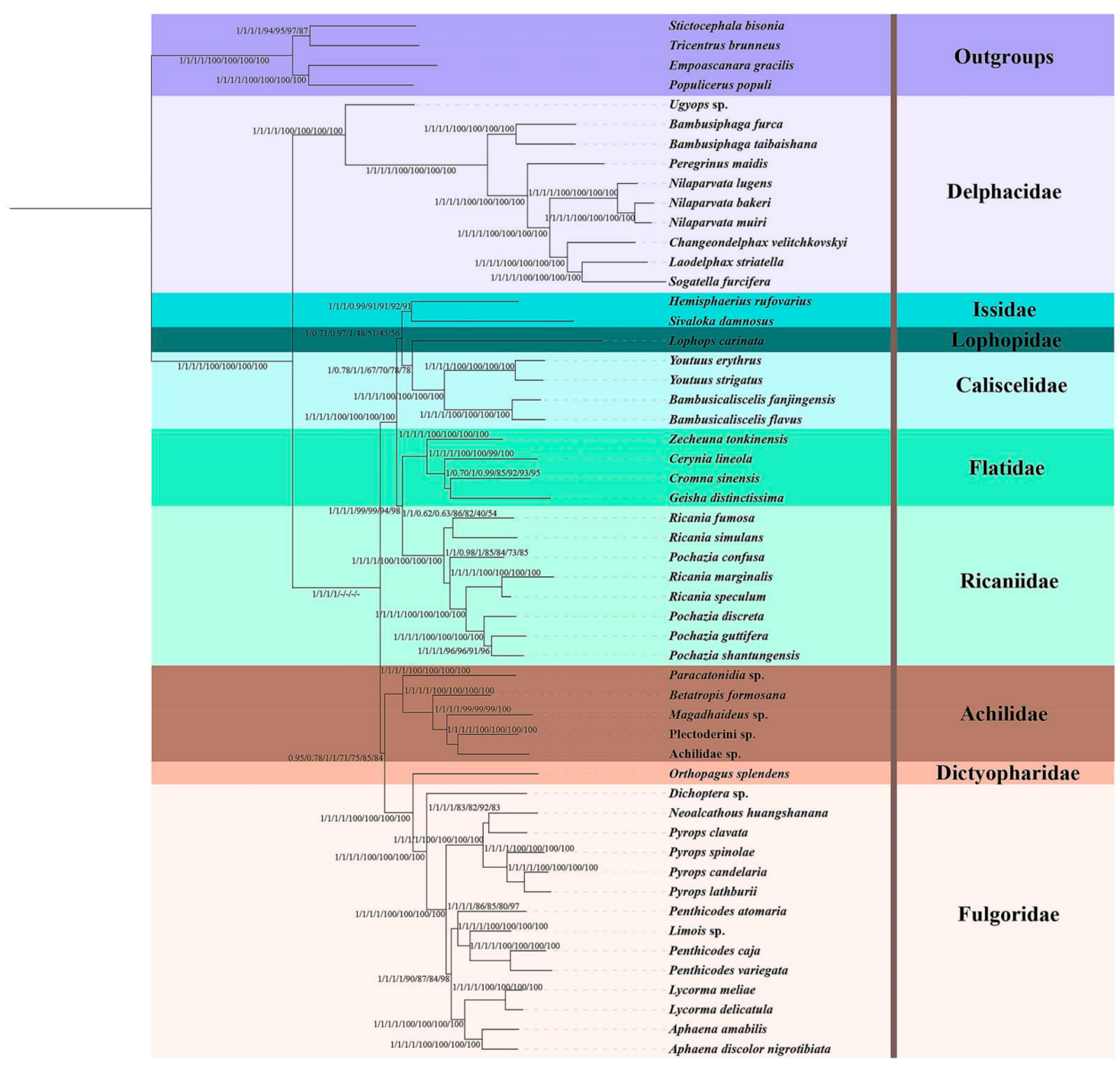

Figure 8. Phylogenetic tree obtained from IQ-TREE and MrBayes based on the data sets of PCG, PCGRNA, PCG12, and PCG12RNA. The numbers at nodes (from left to right) are Bayesian posterior probabilities (PPs) and then ML bootstrap support values (BS). 
The relationship within Ricaniidae in all phylogenetic trees was ((Ricania simulans + Ricania fumosa $)+($ Pochazia confusa $+($ (Ricania speculum + Ricania marginalis $)+($ Pochazia discreta + (Pochazia guttifera + Pochazia shantungensis))))) (Figure 8 and Figures S6-S8). These results recovered Ricania simulans and Ricania fumosa, Ricania speculum and Ricania marginalis as sister taxa, respectively. Similarly, Pochazia shantungensis was placed as sister to Pochazia guttifera.

\section{Discussion}

\subsection{Comparative Analysis of Ricaniid Mitogenomes}

Current evidence shows that Pochazia discreta has the largest size with $16,411 \mathrm{bp}$ while Ricania simulans has the smallest size with 15,457 bp [16-18]. The size variation depends on the variation of length in the control region. Here we found diversity in the repeat unit among the control region of Ricaniid species. The control region of the genus Pochazia had one repeat unit. There are different repeat units in the genus Ricania, but Ricania speculum and Ricania marginalis had two tandem repeat regions with the second repeat unit of "ATAATATAT". Tandem repeats were also found in the control region in other species of Fulgoroidea [18,33-37].

This study found $\operatorname{cox} 2$, atp6, nad4 ended with an incomplete T, which is universal in planthoppers $[33,34,36]$. In addition, nad1 was terminated with incomplete A in Pochazia shantungensis and Ricania speculum, which rarely exists in other planthoppers. Meanwhile, a large segment poly (A), which probably makes mitochondrial genome sequence rather difficult, was found in nad4 and nad5 genes of all five Ricaniidae mitogenomes. It was also found in some other planthoppers species [18,33,34].

\subsection{Nucleotide Diversity of Ricaniid Mitogenomes}

When fully analyzed, the cox 1 gene can provide reliable, rapid species-level classifications and/or species identifications, which have been used by Ceotto et al., (2008), Urban and Cryan (2009), Urban et al., (2010), Gnezdilov et al., (2015), Wang et al., (2016), Huang et al., (2017), Kwon et al., (2017), and Gnezdilov et al., (2020) [13,38-44]. This analysis indicates that the cox 1 gene is the slowest evolving and most relatively conserved compared to other PCGs. The nad2 gene has a relatively faster evolution rate, suggesting that the nad2 gene would be a suitable candidate marker for species classification in Ricaniidae.

\subsection{Phylogeny}

The monophyly of Ricaniidae and the sister grouping of Ricaniidae and Flatidae were supported in all analyses. This was consistent with the explorations of Emeljanov (1990) and Song and Liang (2013) [6,9]. Within Ricaniidae, the phylogenetic relationships among eight species were stable based on different data sets and analytical methods, Ricania speculum was recovered as sister to Ricania marginalis and Pochazia shantungensis grouped with Pochazia guttifera, all with high node support. This was consistent with previous studies of Kang et al., (2020), Lee et al., (2020), Rahman et al., (2012), Bourgoin et al., (2020), and Akiner et al., (2019) [12,16,17,45,46]. In addition, all analyses here failed to support the monophyly of both Pochazia and Ricania, which was congruent with the result of Akiner et al., (2019) [46]. Therefore, the diagnoses between these two genera cannot be resolved until more evidence is acquired.

Prior to this study, two mitochondrial data sets from Pochazia shantungensis and Ricania speculum were found in GeneBank. We think the two mitochondrial sequences of Ricania speculum (Ricania speculum-KX371891 and Ricania speculum-MT834932) are from the same species because the similarity in the two sequences (without the control region) is $99.0 \%$; therefore, any of the two mitochondrial sequences can be used in this analysis. The similarity in the two mitochondrial sequences of Pochazia shantungensis (without the control region) (Ricania shantungensis-MW036196 and Ricania shantungensis-MT898421) from Korea is $93.6 \%$. This genetic gap seemed too big, so we compared the cox1 gene of Pochazia 
shantungensis from China and the cox1 gene of two mitochondrial data sets of Pochazia shantungensis from Korea and found that Ricania shantungensis-MT898421 and Pochazia shantungensis from China had a higher similarity ratio (97.7\%) and were therefore used in this analysis.

The results presented in this paper are the beginning of a new period of research on the phylogenetic position of the family Ricaniidae and its phylogeny and evolution as well as genetic diversity within the family and between species. In addition, the species used in this study will constitute the basis for in-depth research on population and species variability for species that are listed as pests. For example, for Pochazia shantungensis more than 200 host plants ( 81 families, 157 genera) have currently been reported, and for Ricania speculum, more than 140 host plants (54 families, 108 genera) are known (Stroiński, unpublished). Are they related and how? Do they belong to the same genus? Further molecular studies from a larger area of distribution will answer this question.

Supplementary Materials: The following supporting information can be downloaded at: https: / / www.mdpi.com/article/10.3390/biology11010092/s1, Figure S1. The secondary structure for the tRNAs of Pochazia confusa. Figure S2. The secondary structure for the tRNAs of Pochazia discreta. Figure S3. The secondary structure for the tRNAs of Pochazia guttifera. Figure S4. The secondary structure for the tRNAs of Ricania simulans. Figure S5. The secondary structure for the tRNAs of Ricania fumosa. Figure S6. Phylogenetic trees obtained from PhyloBayes based on the data sets of PCG, PCGRNA, PCG12 and PCG12RNA. Figure S7. Phylogenetic trees obtained from IQ-TREE and MrBayes based on the data sets of PCG-AA. Figure S8. Phylogenetic trees obtained from PhyloBayes based on the data sets of PCG-AA. Table S1. Species investigated and their related information. Table S2. Mitogenomic organization of Pochazia confusa. Table S3. Mitogenomic organization of Pochazia discreta. Table S4. Mitogenomic organization of Pochazia guttifera. Table S5. Mitogenomic organization of Ricania simulans. Table S6. Mitogenomic organization of Ricania fumosa. Table S7. Nucleotide composition of mitogenomes of the five species. Table S8. Start and stop codons of eight Ricaniidae mitochondrial genomes. Table S9. Best partitioning schemes and models based on five data sets for IQ-TREE analysis. Table S10. Best partitioning schemes and models based on five data sets for MrBayes analysis.

Author Contributions: Investigation, formal analysis, and writing—original draft, H.Z.; resources, W.F., X.Z. and X.J.; writing-review and editing, H.Z., A.S. and D.Q.; and validation, project administration, and funding acquisition, D.Q. All authors have read and agreed to the published version of the manuscript.

Funding: This study was supported by the National Natural Science Foundation of China (grant numbers 31672340, 31750002, 32170475).

Institutional Review Board Statement: Not applicable.

Informed Consent Statement: Not applicable.

Data Availability Statement: Please see the section Supplementary Materials.

Acknowledgments: We thank John Richard Schrock (Emporia State University, USA) for proofreading of the manuscript and giving us valuable advice. This study was supported by the National Natural Science Foundation of China (grant numbers 31672340, 31750002, 32170475).

Conflicts of Interest: The authors declare no conflict of interest.

\section{References}

1. Bourgoin, T. FLOW (Fulgoromorpha Lists on the Web), Version 8. Available online: http://hemiptera-databases.org/flow / (accessed on 19 August 2021).

2. Rossi, E.; Stroiński, A.; Lucchi, A. Egg morphology, laying behavior and record of the host plants of Ricania speculum (Walker, 1851), a new alien species for Europe (Hemiptera: Ricaniidae). Zootaxa 2015, 4044, 93-104. [CrossRef]

3. Bourgoin, T. Female genitalia in Hemiptera Fulgoromorpha, morphological and phylogenetic data. Ann. Soc. Entomol. Fr. 1993, $29,225-244$.

4. Muir, F. On the classification of the Fulgoroidea (Homoptera). Ann. Mag. Nat. Hist. 1930, 10, 461-478. [CrossRef]

5. Chen, S.; Yang, C.T. The metatarsi of the Fulgoroidea (Homoptera: Auchenorrhyncha). Chin. J. Entomol. 1995, 15, 257-269. 
6. Emeljanov, A.F. An attempt of construction of phylogenetic tree of the planthoppers (Homoptera, Cicadina). Entomol. Obozr. 1990, 69, 353-356.

7. Yeh, W.B.; Yang, C.T.; Hui, C.F. A molecular phylogeny of planthoppers (Hemiptera: Fulgoroidea) inferred from mitochondrial $16 S$ rDNA sequences. Zool. Stud. 2005, 44, 519-535.

8. Urban, J.M.; Cryan, J.R. Evolution of the planthoppers (Insecta: Hemiptera: Fulgoroidea). Mol. Phylogenet. Evol. 2007, 42, 556-572. [CrossRef] [PubMed]

9. Song, N.; Liang, A.P. A preliminary molecular phylogeny of planthoppers (Hemiptera: Fulgoroidea) based on nuclear and mitochondrial DNA sequences. PLoS ONE 2013, 8, e58400. [CrossRef]

10. Fletcher, M.J. A key to the genera of Ricaniidae (Hemiptera: Fulgoromorpha) recorded in Australia with notes on the Australian fauna, including a new species of Epithalamium Kirkaldy. Aust. J. Entomol. 2008, 47, 107-120. [CrossRef]

11. Bu, C.P.; Liang, A.P. First record of the genus Aprivesa Melichar (Hemiptera, Fulgoromorpha) from South India, with description of one new species. Zookeys 2011, 81, 1-12. [CrossRef]

12. Rahman, M.A.; Kwon, Y.J.; Suh, S.J.; Youn, Y.N.; Jo, S.H. The genus Pochazia Amyot and Serville (Hemiptera: Ricaniidae) from Korea, with a newly recorded species. J. Entomol. 2012, 9, 239-247. [CrossRef]

13. Kwon, D.H.; Kim, S.J.; Kang, T.J.; Lee, J.H.; Kim, D.H. Analysis of the molecular phylogenetics and genetic structure of an invasive alien species, Ricania shantungensis, in Korea. J. Asia-Pac. Entomol. 2017, 20, 901-906. [CrossRef]

14. Baek, S.; Lee, J.H.; Park, D.K.; Park, Y.; Kim, M.J.; Kim, K.; Seo, H.Y.; Choi, Y.S. Within-tree distribution of Ricania shantungensis (Hemiptera: Ricaniidae) eggs on chestnuts. J. Asia-Pac. Entomol. 2020, 23, 536-539. [CrossRef]

15. Park, J.; Jung, S. On the scientific name of the invaded planthopper (Hemiptera: Fulgoroidea: Ricaniidae) in Korea. Korean J. Appl. Entomol. 2020, 59, 317-323. [CrossRef]

16. Kang, J.Y.; An, I.; Park, S. The complete mitochondrial genome of Ricania shantungensis (Hemiptera: Ricaniidae) in Korea. Mitochondrial DNA Part B 2020, 5, 3813-3814. [CrossRef] [PubMed]

17. Lee, H.; Park, J.; Xi, H.; Lee, G.S.; Kim, I.; Park, J.; Lee, W. The complete mitochondrial genome of Ricania speculum (Walker, 1851) (Hemiptera: Ricaniidae): Investigation of intraspecific variations on mitochondrial genome. Mitochondrial DNA Part B 2020, 5, 3814-3816. [CrossRef]

18. Song, N.; Liang, A.P.; Bu, C.P. A molecular phylogeny of Hemiptera inferred from mitochondrial genome sequences. PLoS ONE 2012, 7, e48778. [CrossRef]

19. Kearse, M.; Moir, R.; Wilson, A.; Havas, S.S.; Cheung, M.; Sturrock, S.; Buxton, S.; Cooper, A.; Markowitz, S.; Duran, C.; et al. Geneious Basic: An integrated and extendable desktop software platform for the organization and analysis of sequence data. Bioinformatics 2012, 28, 1647-1649. [CrossRef]

20. Grant, J.R.; Stothard, P. The CG View Server: A comparative genomics tool for circular genomes. Nucleic Acids Res. 2008, 36, W181-W184. [CrossRef]

21. Bernt, M.; Donath, A.; Jühling, F.; Externbrink, F.; Florentz, C.; Fritzsch, G.; JoernPütz, J.; Middendorf, M.; Stadler, P.F. MITOS: Improved de novo metazoan mitochondrial genome annotation. Mol. Phylogenet. Evol. 2013, 69, 313-319. [CrossRef]

22. Zhang, D.; Gao, F.; Jakovlić, I.; Zou, H.; Zhang, J.; Li, W.X.; Wang, G.T. PhyloSuite: An integrated and scalable desktop platform for streamlined molecular sequence data management and evolutionary phylogenetics studies. Mol. Ecol. Resour. 2020, 20, 348-355. [CrossRef] [PubMed]

23. Benson, G. Tandem repeats finder: A program to analyze DNA sequences. Nucleic Acids Res. 1999, 27, 573-580. [CrossRef] [PubMed]

24. Rozas, J.; Ferrer-Mata, A.; Sánchez-DelBarrio, J.C.; Guirao-Rico, S.; Librado, P.; Ramos-Onsins, S.E.; Sánchez-Gracia, A. DnaSP 6 : DNA sequence polymorphism analysis of large datasets. Mol. Biol. Evol. 2017, 34, 3299-3302. [CrossRef]

25. Kumar, S.; Stecher, G.; Li, M.; Knyaz, C.; Tamura, K. MEGA X: Molecular evolutionary genetics analysis across computing platforms. Mol. Biol. Evol. 2018, 35, 1547-1549. [CrossRef]

26. Katoh, K.; Standley, D.M. MAFFT multiple sequence alignment software version 7: Improvements in performance and usability Mol. Biol. Evol. 2013, 30, 772-780. [CrossRef]

27. Talavera, G.; Castresana, J. Improvement of phylogenies after removing divergent and ambiguously aligned blocks from protein sequence alignments. Syst. Biol. 2007, 56, 564-577. [CrossRef]

28. Kück, P.; Meid, S.A.; Groß, C.; Wägele, J.W.; Misof, B. AliGROOVE—Visualization of heterogeneous sequence divergence within multiple sequence alignments and detection of inflated branch support. BMC Bioinform. 2014, 15, 294. [CrossRef]

29. Lanfear, R.; Frandsen, P.B.; Wright, A.M.; Senfeld, T.; Calcott, B. PartitionFinder 2: New methods for selecting partitioned models of evolution for molecular and morphological phylogenetic analyses. Mol. Biol. Evol. 2017, 34, 772-773. [CrossRef] [PubMed]

30. Nguyen, L.T.; Schmidt, H.A.; Haeseler, A.V.; Minh, B.Q. IQ-TREE: A fast and effective stochastic algorithm for estimating maximum-likelihood phylogenies. Mol. Biol. Evol. 2015, 32, 268-274. [CrossRef] [PubMed]

31. Ronquist, F.; Teslenko, M.; Mark, P.V.D.; Ayres, D.L.; Darling, A.; Höhna, S.; Larget, B.; Liu, L.; Suchard, M.A.; Huelsenbeck, J.P. MrBayes 3.2: Efficient Bayesian phylogenetic inference and model choice across a large model space. Syst. Biol. 2012, 61, 539-542. [CrossRef] [PubMed]

32. Miller, M.; Pfeiffer, W.T.; Schwartz, T. Creating the CIPRES science gateway for inference of large phylogenetic trees. In Proceedings of the Gateway Computing Environments Workshop (GCE), New Orleans, LA, USA, 14 November 2010; Institute of Electrical and Electronics Engineers (IEEE): New Orleans, LA, USA, 2010; pp. 1-8. [CrossRef] 
33. Wang, W.Q.; Huang, Y.X.; Bartlett, C.R.; Zhou, F.M.; Meng, R.; Qin, D.Z. Characterization of the complete mitochondrial genomes of two species of the genus Aphaena Guérin-Méneville (Hemiptera: Fulgoridae) and its phylogenetic implications. Int. J. Biol. Macromol. 2019, 141, 29-40. [CrossRef] [PubMed]

34. Wang, W.Q.; Zhang, H.; Constant, J.; Bartlett, C.R.; Qin, D.Z. Characterization, comparative analysis and phylogenetic implications of mitogenomes of Fulgoridae (Hemiptera: Fulgoromorpha). Genes 2021, 12, 1185. [CrossRef]

35. Xu, S.Y.; Long, J.K.; Chen, X.S. Comparative analysis of the complete mitochondrial genomes of five Achilidae species (Hemiptera: Fulgoroidea) and other Fulgoroidea reveals conserved mitochondrial genome organization. Peer] 2019, 7, e6659. [CrossRef] [PubMed]

36. Ai, D.Q.; Peng, L.F.; Qin, D.Z.; Zhang, Y.L. Characterization of three complete mitogenomes of Flatidae (Hemiptera: Fulgoroidea) and compositional heterogeneity analysis in the planthoppers' mitochondrial phylogenomics. Int. J. Mol. Sci. 2021, $22,5586$. [CrossRef] [PubMed]

37. Gong, N.; Yang, L.; Chen, X.S. Structural features and phylogenetic implications of four new mitogenomes of Caliscelidae (Hemiptera: Fulgoromorpha). Int. J. Mol. Sci. 2021, 22, 1348. [CrossRef]

38. Ceotto, P.; Kergoat, G.J.; Rasplus, J.Y.; Bourgoin, T. Molecular phylogenetics of cixiid planthoppers (Hemiptera: Fulgoromorpha): New insights from combined analyses of mitochondrial and nuclear genes. Mol. Phylogenet. Evol. 2008, 48, 667-678. [CrossRef]

39. Urban, J.M.; Cryan, J.R. Entomologically famous, evolutionarily unexplored: The first phylogeny of the lanternfly family Fulgoridae (Insecta: Hemiptera: Fulgoroidea). Mol. Phylogenet. Evol. 2009, 50, 471-484. [CrossRef]

40. Huang, Y.X.; Zheng, L.F.; Bartlett, C.R.; Qin, D.Z. Resolving phylogenetic relationships of Delphacini and Tropidocephalini (Hemiptera: Delphacidae: Delphacinae) as inferred from four genetic loci. Sci. Rep. 2017, 7, 3319. [CrossRef]

41. Urban, J.M.; Bartlett, C.R.; Cryan, J.R. Evolution of Delphacidae (Hemiptera: Fulgoroidea): Combined-evidence phylogenetics reveals importance of grass host shifts. Syst. Entomol. 2010, 35, 678-691. [CrossRef]

42. Wang, M.L.; Zhang, Y.L.; Bourgoin, T. Planthopper family Issidae (Insecta: Hemiptera: Fulgoromorpha): Linking molecular phylogeny with classification. Mol. Phylogenet. Evol. 2016, 105, 224-234. [CrossRef]

43. Gnezdilov, V.M.; Bourgoin, T.; Mozaffarian, F.; Manzari, S. Difficulties in building a molecular phylogeny of the issidoid planthopper lineages (Insecta: Hemiptera: Fulgoroidea). In Proceedings of the 1st Iranian International Congress of Entomology, Tehran, Iran, 29-31 August 2015; pp. 218-227.

44. Gnezdilov, V.M.; Konstantinov, F.V.; Bodrov, S.Y. New insights into the molecular phylogeny and taxonomy of the family Issidae (Hemiptera: Auchenorrhyncha: Fulgoroidea). Proc. Zool. Inst. RAS 2020, 324, 146-161. [CrossRef]

45. Akiner, M.M.; Beris, F.S.; Seyis, F.; Ozturk, M.; Sevgili, H.; Demir, E. Annual variation of the Orosanga japonica Melichar 1898 (Hemiptera: Ricaniidae) populations in the eastern Black Sea region of Turkey and possible molecular separation with based on $28 S$ rDNA sequences from other Ricaniidae groups. Plant Prot. Bull. 2019, 59, 11-19. [CrossRef]

46. Bourgoin, T.; Gros, P.; Stroiński., A. Pochazia shantungensis (Chou \& Lu, 1977), an important Asiatic invasive pest on fruit trees, first time reported from France (Hemiptera, Fulgoromorpha, Ricaniidae). Bull. Soc. Entomol. Fr. 2020, 125, 271-272. [CrossRef] 